\title{
Factors Affecting Marketing of Vegetables among Small-Scale Farmers in Mahikeng Local Municipality, North West Province, South Africa
}

\author{
S.H Matsane \\ A.S Oyekale \\ Department of Agricultural Economics and Extension. North-West University, \\ Mafikeng Campus, Mmabatho 2735. South Africa.
}

Doi:10.5901/mjss.2014.v5n20p390

\section{Abstract}

Agricultural produce from small-scale farmers is often lost after production due to so many marketing challenges which make it difficult for small-scale farmers to explore full market potentials and they also reduce incentives of participation in formal (commercial) or high-value markets. The main objective of the study was to identify and analyse factors affecting (constraints) marketing of vegetables among small-scale farmers. Data were collected with structured questionnaire and analyzed using descriptive and regression analysis. Results showed that prominent constraints of marketing vegetables among the small-scale farmers were: lack of access to credit, lack of access to storage facilities, lack of market information, lack of finance for farming, poorly developed village markets, poor producer prices, high perishability of produce, low patronage, inadequate access roads, small size of transport and high transportation costs. Variables that significantly influenced monthly net farm income were: gender ( $(=3.913)$, farm size $(t=4.100)$, number of employees $(t=6.126)$, access to storage $(t=-2.132)$, grading of products ( $t$ $=3.712$ ) and access to extension services $(t=1.757)$. Recommendations suggested include: enabling accessibility through the development of better infrastructure in the form of storage facilities, roads for transportation and communication systems; and the formation of marketing cooperatives to overcome high transportation costs, small size of transport and individual small marketing output problems in order to attract and penetrate high value-markets.

Keywords: Small-Scale Vegetable Farmers. Factors Affecting Marketing. Socio-Economic Characteristics.

\section{Introduction}

Agriculture is important to the society in terms of poverty alleviation, food security and economic growth. It is the backbone of many African economies (Balarane \& Oladele, 2011). Many people depend on agriculture for their livelihoods (World Development Report, 2008). An estimated 86 percent of rural people rely on agriculture as a livelihood option and it provides jobs for 1.3 billion smallholders and landless workers (Tita, 2008/9). Since the mid-eighties, the Government of India identified horticulture (vegetable) crops as a means of diversification for making agriculture more profitable through efficient land use, optimum utilization of natural resources and creating skilled employment for rural masses (Samantaray et al., 2009).

In South Africa, the agricultural sector comprises of the well-developed commercial farming (Antwi \& Seahlodi, 2011), which has a small number of commercial operators predominantly operated by white farmers (Senyolo et al., 2009), and more subsistence-based production in the deep rural areas (Antwi \& Seahlodi, 2011) operated by black farmers (Senyolo et al., 2009).

The sharp division between small scale and commercial farming further explains why unequal distribution of agricultural inputs such as land, farm assets, support services, market access, infrastructure and income persists in South Africa. The subsistence sector involves small-scale production which is highly labour intensive with low farm capital investment and little division of labour (Antwi \& Seahlodi, 2011). Also, majority of small-scale farmers lack access to adequate marketing facilities, which when exist are grossly underdeveloped and inefficient (Adeleke et al., 2010). Among commercial farmers, however, there is high capital investment, high levels of divisions of labour and patronage of both local and international markets (Antwi \& Seahlodi, 2011). Agricultural development will not occur without engaging smallscale farmers who account for the overwhelming majority of actors in this sector and engaging in profitable agriculture means generating maximum returns from the resources expended and formal markets (Barham \& Chitemi, 2009).

Marketing is a business activity associated with the flow of goods and services from producers to consumers (Antwi \& Seahlodi, 2011). Marketing of agricultural products begins on the farm with planning of production to meet 
specific demand and market prospects (Bothloko \& Oladele, 2013). Marketing information and market prices guide the farmer in making informed decisions (Uchezuba et al., 2009), and also assist farmers for planning at pre-planting stage and to sell the surpluses that have been produced. In the absence of marketing information, the retail end of the industry does not respond to supply and demand and the pricing is artificially static or unchanged (Xaba \& Masuku, 2012).

Marketing plays a critical role in meeting the overall goals of economic development (Bothloko \& Oladele, 2013), food security, poverty alleviation and sustainable agriculture, especially among smallholder farmers in developing countries (Xaba \& Masuku, 2012). Deficiencies in rural infrastructure services result in poor functioning domestic markets with little spatial and temporal integration, low price transmission and weak international competitiveness (Senyolo et al., 2009).

Marketing constraints or challenges arise due to many factors such as limited knowledge and use of market information, lack of access to high-value reliable markets, high transactional costs, distance from the markets, poor quality of products, lack of storage facilities, low educational levels of small-scale farmers, poor agricultural extension services, lack of financial support (Antwi \& Seahlodi, 2011), inadequate property rights (Matungul et al., 2002), inadequate and inaccessible market infrastructure, lack of adequate access to finance, socio-economic factors of the farmer, for example: training, farming experience, age, level of education and household size, lack of access to decent roads, price risk and uncertainty, electricity, poor communication (Senyolo et al., 2009), information regarding prices, inadequate local markets, lack of bargaining power, excess of intermediaries (Xaba \& Masuku, 2012).

These marketing constraints constitute the greatest barrier for small-scale farmers when it comes to access highvalue markets (Baloyi, 2010), and these factors restrain farmers from making decisions to participate in the market (Uchezuba et al., 2009). Access to markets is an essential requirement for the poor in rural areas. It may also be easy to access markets, but retaining one's position in the market is more difficult and participation of small-scale farmers in high-value markets is unsatisfactory (Baloyi, 2010), and the perishable nature of vegetables necessitate effective marketing channels (Xaba \& Masuku, 2012). Therefore, overcoming marketing constraints is critical for small-scale farmers to access lucrative markets (Baloyi, 2010). Shifting the focus from production-oriented programmes to more market-oriented interventions will place a renew attention on institutions of collective action, such as farmer groups, as an efficient mechanism for enhancing market performance (Barham \& Chitemi, 2009)

The main objective of the study was to identify and analyse factors affecting marketing of vegetables among smallscale farmers in Mahikeng Local Municipality. The specific objectives of the study were to identify and analyse demographics; socio-economic characteristics of the small-scale vegetable farmers in the study area; the factors affecting marketing vegetables; and the effect of socio-economic and personal characteristics on the farmers' monthly net farm incomes.

\section{Methodology}

The study was conducted in Mahikeng Local Municipality, Ngaka Modiri Molema District in the North West Province. It is located on South Africa's border with Botswana. The total area of the Mahikeng Local Municipality is approximately 3703 $\mathrm{km} 2$. It is divided into 28 wards consisting of 102 Villages and suburbs. The coordinates are $25^{\circ} 51^{\prime} \mathrm{S}$ and $25^{\circ} 38^{\prime} \mathrm{E}$. (Fig 1 )

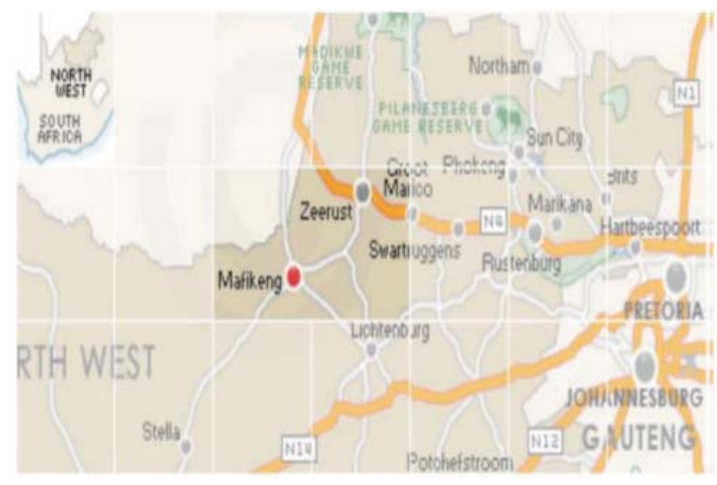

Figure 1: The map of Mahikeng Local Municipality, Ngaka Modiri Molema District of North West province 
The main economic activity in the Ngaka Modiri Molema District of the North West Province is Agriculture, mainly producing crops and cattle. According to Materechera (2011), the climate in the study area is typical semi-arid savannah with a mean annual summer rainfall of $500 \mathrm{~mm}$. Balarane and Oladele (2012) stated that temperatures in the study area range from $17^{\circ}$ to $31^{\circ} \mathrm{C}\left(62^{\circ}\right.$ to $\left.88^{\circ} \mathrm{F}\right)$ in the summer and from $3^{\circ}$ to $21^{\circ} \mathrm{C}\left(37^{\circ}\right.$ to $\left.70^{\circ} \mathrm{F}\right)$ in the winter. The total (93) population of this study were both males and females small-scale vegetable farmers in Mahikeng Local Municipality.

A simple random sampling method was used to draw a sample size of 47 small-scale vegetable farmers from the target population. Primary data were obtained by using a well-structured questionnaire as a data collection tool. The questionnaire was designed to elicit data on the demographic data, marketing constraints/challenges and socio-economic characteristics. The questions in the questionnaire were both closed and open-ended questions. The data from completed questionnaires were coded, captured and analysed using Statistical Package for Social Sciences (SPSS) version 21.

Descriptive statistics (frequencies and percentages) was employed in order to determine the factors/constraints among the small-scale vegetable farmers, while multiple regression analysis was employed in order to analyse the effects of socio-economic characteristics on the monthly net farm incomes of the small-scale vegetable farmers from vegetable sales. The multiple regression model was specified as shown below. The assumptions of least square method regarding linearity, normality and homoscedasticity were ensured.

$Y i=a+b 1 X 1+b 2 X 2+b 3 X 3+b 4 X 4+b 5 X 5+b 6 X 6+b 7 X 7+\ldots+b n X n+e i$

Where: $Y i=$ Monthly net incomes of the respondents in Rands (dependent variable); and the independent variables are:- $\mathrm{X} 1=$ Gender; $\mathrm{X} 2=\mathrm{Age} ; \mathrm{X} 3=$ Marital Status; $\mathrm{X} 4=$ Educational Level; $\mathrm{X} 5=$ Number of dependents; $\mathrm{X} 6=$ Farm size in cultivation; $X 7=$ Number of employees; $X 8=$ Non-farming activities; $X 9=$ Access to storage facilities; $X 10=$ Grading of products; $X 11=$ Access to market information; X12 = Borrow money for farming activities; $X 13=$ Keeping of marketing records; $\mathrm{X} 14$ = Access to extension services and ei= Error term

\section{Results and Discussion}

Table 1 below shows the demographic characteristics for the small-scale vegetable farmers in the study area. It indicates that $21.3 \%$ of the farmers fell within the group of $20-39$ years, $41.7 \%$ within $40-59$ years, $27.7 \%$ within $60-79$ years and $8.5 \%$ was above 80 years old. The lack of interest of young people in farming may have a negative impact on agricultural development because the current farmers are aging. This may be because of the emigration of young people from rural areas to urban areas for non-agricultural jobs. The results also revealed that $40.4 \%$ of the farmers were males and $59.6 \%$ were females. These findings indicate that the study area was female dominant in vegetable production. This may be because vegetable production is very tedious to the extent that man cannot cope or might be because women take most responsibility of their household food security.

The results on Table 1 also show 44.7\% of the respondents were married. According to Moobi and Oladele (2012), high percentage of married farmers helps to provide family labour. The results also show $48.9 \%$ high school level of education among the farmers. According Bothoko and Oladele (2013), literate farmers are likely to adopt new innovation than illiterate farmers, hence, their productivity increases and greater farms' returns. Majority (78.7\%) of the farmers had farming experience of less than or equal to twenty years. Bothoko and Oladele (2013) stated that farming experience is important, thus, it comes with year of practice. The average farm size and size in cultivation of the farmers were 50.9ha and 13.9ha respectively. According to Bothoko and Oladele (2013), farm size has no effect to greater returns because small farms can produce far more per hectare than large farms.

The findings in Table 1 further show that majority (53.2\%) of the farmers acquired their land through communal tenure. The land tenure by communal which is predominant pattern of land ownership does not ensure security, but personal land tenure ensures security and sustainable use of land which is essential to maximize farm investment and returns. The findings also show that $83.0 \%$ of the farmers had contact with government extension agents. This imply that most of the farmers in the study area are likely to increase agricultural production and productivity due to the knowledge, demonstrations and the information received from the agents which may shift the balance between success and failure of the farmers. The average monthly net farm income of the farmers was R5 161 . This shows that majority of the farmers return from vegetable sales was low. This may be because of poor producer price, lack of markets and patronage. Table 1 further shows that almost all the farmers (93.6\%) in the area had farming as their primary occupation which also reviews farming as their source of income. According to Bothoko and Oladele (2013), people make use of agriculture to ensure food security, hence, income generation. 
Table 1: Demographic and personal characteristics of respondents

\begin{tabular}{|c|c|c|}
\hline Variables & Frequency & Percentage \\
\hline \multicolumn{3}{|l|}{ Age } \\
\hline $20-39$ & 10 & 21.3 \\
\hline $40-59$ & 20 & 41.7 \\
\hline $60-79$ & 13 & 27.7 \\
\hline$\geq 80$ & 4 & 8.5 \\
\hline \multicolumn{3}{|l|}{ Gender } \\
\hline Male & 19 & 40.4 \\
\hline Female & 28 & 59.6 \\
\hline \multicolumn{3}{|l|}{ Marital Status } \\
\hline Single & 18 & 38.3 \\
\hline Married & 21 & 44.7 \\
\hline Divorced & 3 & 6.4 \\
\hline Widow & 5 & 10.6 \\
\hline \multicolumn{3}{|l|}{ Educational level } \\
\hline None & 3 & 6.4 \\
\hline Primary & 14 & 29.8 \\
\hline Secondary school & 23 & 48.9 \\
\hline Post-secondary & 7 & 14.9 \\
\hline \multicolumn{3}{|l|}{ Years in Farming/experience } \\
\hline$\leq 20$ & 37 & 78.7 \\
\hline $21-60$ & 8 & 17.0 \\
\hline$\geq 61$ & 2 & 4.3 \\
\hline \multicolumn{3}{|l|}{ Farm size (ha) } \\
\hline$\leq 50$ & 39 & 83.0 \\
\hline $51-100$ & 4 & 8.5 \\
\hline$\geq 101$ & 4 & 8.5 \\
\hline \multicolumn{3}{|l|}{ Land tenure } \\
\hline Personal & 20 & 42.6 \\
\hline Communal & 25 & 53.2 \\
\hline Rented & 2 & 4.2 \\
\hline \multicolumn{3}{|l|}{ Extension services/contact } \\
\hline Yes & 39 & 83.0 \\
\hline No & 8 & 17.0 \\
\hline \multicolumn{3}{|l|}{ Level of farm income (R) } \\
\hline $0-1000$ & 7 & 14.9 \\
\hline $1001-5000$ & 23 & 48.9 \\
\hline $5001-10000$ & 13 & 27.6 \\
\hline$\geq 10001$ & 4 & 8.6 \\
\hline \multicolumn{3}{|l|}{ Non-farming activities } \\
\hline Yes & 3 & 6.4 \\
\hline No & 44 & 93.6 \\
\hline
\end{tabular}

Table 2 presents socio-economic characteristics of the farmers' rural communities. Majority (61.7\%) of the farmers indicated the aged of agricultural owner-operators and agricultural workers. This may be because of emigration of young people from agriculture to seek for better jobs in urban areas. The results also show $83.0 \%$ and $51.1 \%$ level of unemployment rate and degree of remoteness respectively. This may be because most of the people in rural areas are illiterate and situated far from market areas. Table 2 further shows that $51.1 \%$ and $59.6 \%$ of the farmers indicated high level of lack of marketing information available and the need for support and training for marketing service personnel respectively. Table 2 further shows that about $75 \%$ of the farmers indicated the need for communication strategies that facilitate effective flow of information between government agencies and farming communities. This may be the results of inappropriate ratio of government agencies to farmers. Moobi and Oladele (2012) stated that the ratio of government extension agents to farmers in the study area is 1: 500. In this situation, the government extension agents may not be able to visit all farmers within a week, hence productivity level declines. 
Table 2: The socio-economic characteristics of the farmers' rural communities

\begin{tabular}{|c|c|c|c|}
\hline Socio-economic variables & High & Moderate & Low \\
\hline Aged of agricultural owner-operators and agricultural workers & $8(17.0)$ & $29(61.7)$ & $10(21.3)$ \\
\hline Unemployment rate & $39(83.0)$ & $7(14.9)$ & $1(2.1)$ \\
\hline Degree of remoteness & $24(51.1)$ & $17(36.2)$ & $6(12.8)$ \\
\hline The lack of marketing information available for farmers & $24(51.1)$ & $20(42.6)$ & $3(6.4)$ \\
\hline The need for support and training for marketing service personnel & $28(59.6)$ & $18(38.3)$ & $1(2.1)$ \\
\hline $\begin{array}{l}\text { The need for communication strategies that facilitate effective flow of information between } \\
\text { government agencies and farming communities }\end{array}$ & $35(74.5)$ & $12(25.5)$ & $0(0.0)$ \\
\hline
\end{tabular}

Table 3 shows results factors (constraints) affecting marketing of vegetables among the small-scale farmers in the study area. The results show that $87.2 \%$ and $53.2 \%$ of farmers did not have access to credit and storage facilities respectively. The lack of access to credit may be because many small-scale farmers do not have properties that may be held as collateral and may also result from the lack of information about available sources of lenders, types of credits offered and the interest rates charged by borrowers. According to Ozowa (1995) stated that awareness of existing loan facilities is inhibited by low level of literacy among small-scale farmers. Adeleke et al., (2010) stated that the main reason for commercial banks not to lend money to agricultural enterprises is because of it being risky. Cong et al., (2006) stated that due to the lack of storage facilities, farmers tend to use traditional techniques which causes humidity to produce, high loss and reduce quality of produce for small-scale farmers.

Table 3 further shows that majority (85.1\%) of the farmers did not have access to marketing information. According to Dorward and Kydd (2005), businesses in rural areas is attributed by weak information on potential market players, prices and innovations. Saxena (2008) further stated that producers are often in agricultural practices, but not in effective and efficient marketing methods. Majority (57.4) of the farmers did not grade their produce before being sold and this may have led decline in farm income. The results also show that $100.0 \%$ of the farmers did not have insurance against natural disasters, loss of income, theft and fluctuating market prices. According to Newton (2013), insurance could be used as collateral for loans and it also enforces farmers to improve on farming standards for them to be eligible for payments on incurring losses.

Table 3: Factors (constraints) affecting marketing of vegetables among the small-scale farmers in the study area

\begin{tabular}{|c|c|c|c|c|}
\hline \multicolumn{2}{|l|}{ Constraints } & \multicolumn{2}{|c|}{ Yes } & \multirow{2}{*}{$\begin{array}{l}\text { No } \\
\%\end{array}$} \\
\hline Frequency & & $\%$ & Frequency & \\
\hline Access to credit & 6 & 12.8 & 41 & 87.2 \\
\hline Access to storage & 22 & 46.8 & 25 & 53.2 \\
\hline Grading of produce & 20 & 42.6 & 27 & 57.4 \\
\hline Access to marketing information & 7 & 14.9 & 40 & 85.1 \\
\hline Insurance against theft, drought, frost, loss of income: & 0 & 0.0 & 47 & 100.0 \\
\hline
\end{tabular}

Figure 1 shows the level of factors (constraints) affecting marketing of vegetable as indicated by the small-scale vegetable farmers in the study area. The results show that about $63.8 \%$ farmers experienced low patronage. This may result from inconsistency in production and persistence supply of produce to consumers. The results also show that $74.5 \%$ and $70.2 \%$ of the farmers experienced poorly developed village markets and the lack of credit for veg-processing respectively. This may be due to the lack of credit information among the small-scale farmers. Cong et al., (2007) stated that the lack of processing facilities and processing knowledge is also a constraint among small-scale farmers.

The results in Figure 1 further show that about 59.6\% farmers were also constrained by the lack or poor market access roads. These may have limited transportation of product for better markets. However, it may have also retarded quick distribution of produce after harvesting, hence, perishability of the products. Thus, less income that could be made from sales of low quantity and poor quality products. Adeleke et al., (2010) stated that road systems are the most serious infrastructural bottleneck facing agricultural development. 


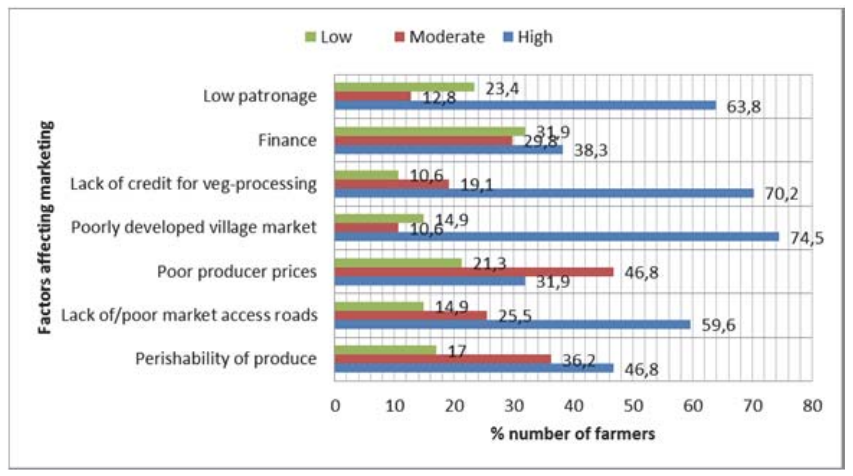

Figure 1: The level of factors (constraints) affecting marketing of vegetable among the small-scale farmers

Table 4 shows the results of other factors affecting the small-scale vegetable farmers in marketing their produce. The results show that about $48.9 \%$ of the farmers sold their produce in both farm gate and local village markets but majority on farm gate. These maybe due to the small quantity produced, poor quality and lack of contract marketing. Table 4 also shows that majority (57.4\%) of the farmers were located more than five kilometres away from market places. This may be because many small-scale farmers stay in former home lands which are far from market places. The results further show that about $72.3 \%$ of the farmer adopted an individual marketing system. This may be associated with the lack of knowledge in the formation of group or cooperative marketing among the farmers. Majority (61.7\%) of the farmers hired transport to distribute farm produce to their village market points and the problems mostly associated when distributing their produce to the markets were small size of transport, high transport costs \& lack/poor transport.

Table 4: Other factors affecting the small-scale vegetable farmers in marketing their produce

\begin{tabular}{l|c|c}
\hline \multicolumn{1}{c|}{ Constraints } & Frequency & $\%$ \\
\hline Product market place & 11 & 24.3 \\
- Farm gate & 6 & 12.8 \\
- Local village markets & 1 & 2.1 \\
- Supermarkets & 23 & 48.9 \\
- Farm gate \& Local village markets & 1 & 2.1 \\
- Local markets \& Supermarkets & 7 & 10.6 \\
- All of the above & & \\
Distance from farm to market places & 2 & 4.3 \\
- - 2km & 18 & 38.3 \\
- - 4km & 27 & 57.4 \\
- 5km & & \\
Marketing systems adopted & 34 & 72.3 \\
- Individual marketing & 1 & 2.1 \\
- Contract marketing & 3 & 6.4 \\
- Group/cooperative marketing & 6 & 12.8 \\
- Individual \& contract marketing & 3 & 6.4 \\
- All of the above & & \\
The ownership of transport to transfer produce to market points & 15 & 31.9 \\
- Own transport & 29 & 61.7 \\
- Hired transport (individual) & 3 & 6.4 \\
- Hired transport (group) & & \\
Problems experienced when moving produce to markets & 3 & 6.4 \\
- None & 5 & 10.6 \\
- Lack/poor transport & 8 & 17.0 \\
- High transport costs & 11 & 23.4 \\
- Small size of transport & 4 & 8.5 \\
- Damage to produce, Small size of transport \& High transport costs & 16 & 34.0 \\
- Small size of transport, High transport costs \& Lack/poor transport & & \\
\hline & &
\end{tabular}


Table 5 presents the results of the multiple regression on the effects of the socio-economic and personal characteristics of the farmers on their monthly net farm income. A deterministic regression function was employed to the data and the regression estimates of the relationship between dependent variable (farmers' monthly net farm income) and independent variables (socio-economic and personal characteristics) were determined. The independent variables were significantly related to the farmers' monthly net farm income with $F$ value of 9.406 at $p<0.001$. Also, $R$ value of 0.897 shows that there was a strong correlation between independent variables and farmers' monthly net income (dependent variable).

The results in Table 5 further predicted 80.4 percent $(R 2=0.804)$ variation in the dependent variable was explained by the independent variables. Durbin-Watson statistics was 2.135. Fourteen independent variables were used. However, six out of the fourteen independent variables had statistically significant effect on the dependent variable (farmers' monthly net farm income). The significant independent variables were: gender $(t=3.913)$; farm size in cultivation ( $\mathrm{t}=4.100)$; number of employees $(\mathrm{t}=6.126)$; access to storage facilities $(\mathrm{t}=-2.132)$; grading of products $(\mathrm{t}=$ 3.335) and access to extension services $(t=1.757)$. These findings imply that an increase the number of males in farming, increase farm size in cultivation, employees, grading of products and improved extension services could increase the monthly net farm income. However, it declines with the decreasing of access to storage facilities.

Table 5: Parameter estimates of the multiple regression analysis of the effects of socio-economic factors and personal characteristics on the monthly net farm income of the small scale vegetable farmers

\begin{tabular}{l|cc|ccc|c}
\hline \multicolumn{1}{c|}{ Variables } & \multicolumn{3}{c|}{ Unstandardized coefficients } & \multicolumn{3}{c}{ Standardized coefficients } \\
\hline \multicolumn{1}{c|}{ B } & & Std. Error & Beta & t-test & Sig. \\
\hline Constant & 2126.431 & 3431.852 & .353 & .620 & .540 \\
Gender & 3818.118 & 975.854 & -.183 & 3.913 & $.000^{* * *}$ \\
Age & -56.480 & 38.538 & .138 & -1.466 & .153 \\
Marital status & 1485.724 & 1466.622 & .053 & 1.013 & .319 \\
Educational level & 1141.697 & 2041.731 & -.046 & .559 & .580 \\
Number of dependents & -120.103 & 241.317 & .392 & -.498 & .622 \\
Farm size & 68.538 & 16.715 & .552 & 4.100 & $.000^{* * *}$ \\
Number of employees & 514.562 & 83.990 & -.046 & 6.126 & $.000^{* * *}$ \\
Non-farming activities & -502.607 & 1094.582 & -.259 & -.459 & .649 \\
Access to storage & -2757.747 & 1293.620 & .368 & -2.132 & $.041^{*}$ \\
Grade of products & 3951.485 & 1064.507 & -.005 & 3.712 & $.001^{* *}$ \\
Access to market information & -71.888 & 1639.936 & .148 & -.044 & .965 \\
Borrow money for farming activities & 1951.837 & 1206.756 & -.111 & 1.617 & .116 \\
Keeping of marketing records & -2406.744 & 2122.373 & .181 & -1.134 & .265 \\
Access to extension services & 2555.132 & 1454.605 & & 1.757 & $.089^{*}$ \\
R & .897 & & & & \\
R2 & .804 & & & & \\
Adjusted R2 & .719 & & & & & \\
Durbin-Watson & 2.135 & & & & \\
F & 9.406 & $.000^{* * *}$ & & & \\
P & & & &
\end{tabular}

Figures in parentheses are significant: * significant at $1 \%$; ** significant at $5 \%$ and *** significant at $10 \%$

\section{Conclusion and Recommendation}

Marketing of vegetables plays a critical role in meeting the overall goals of sustainable agriculture, food security and poverty alleviation, particularly among small-scale farmers in rural areas. Prominent constraints of marketing vegetables among the small-scale farmers were: lack of access to credit, lack of access to storage facilities, lack of market information, lack of finance for farming, poorly developed village markets, poor producer prices, high perishability of produce, low patronage, inadequate access roads, small size of transport and high transportation costs. Significant determinants gender; farm size in cultivation; number of employees; access to storage facilities; grading of products and access to extension services. In view of the results, it is therefore recommended that, the formation of marketing cooperatives would enable the farmers to market their products together to address individual small marketing output constraints, small size of transport and high transportation costs in order to attract and penetrate high value-markets. There is also a need to provide effective and efficient quality extension services in order to equip farmers with important skills in the areas of vegetable production and supply of useful marketing information for the farmers. Emphasis should 
also be on enabling accessibility through the development of better infrastructure in the form of storage facilities, roads for transportation and communication systems.

\section{References}

Adeleke S, Abdul B.K, \& Zuzana B, (2010). Smallholder Agriculture in East Africa: Trends, Constraints and Opportunities. African development group, working paper series No 105 African Development Bank, Tunis, Tunisia. Internet file retrieved on $11^{\text {th }}$ May 2013 from: http://www.afdb.org/fileadmin/uploads/afdb/Documents/Publications/WORKING\%20105\%20\%20PDF\%20d.pdf

Antwi M and Seahlodi P, (2011). Marketing Constraints Facing Emerging Small-Scale Pig Farmers in Gauteng Province, South Africa. Journal of Human Ecology, 36(1): 37-42

Balarane A, and Oladele O.I, (2012). Awareness and use of agricultural market information among small scale farmers in Ngaka Modiri Molema District of North West Province. Life Science Journal, 9(3): 57 - 62

Bothoko G.J and Oladele O.I, (2013). Factors Affecting Farmers Participation in Agricultural projects in Ngaka Modiri Molema District North West Province, South Africa. Journal of Human Ecology, 41(3): 201-206

Tita D.F, (2008/9). A transaction cost analysis of factors affecting market arrangements in the agroforestry tree product value chain in Cameroon. Internet file retrieved on 31st March 2013 from: http://www.worldagroforestry.org/downloads/ publications/PDFs/ B16462.PDF

Dorward A, and Kydd J, (2005). Making agricultural market systems work for the poor: Promoting effective, efficient and accessible coordination and exchange. Internet file retrieved on $1^{\text {st }}$ June 2013 from: http://goviya.hostzi.com/adb-workshopmakingagriculture.pdf.

Barham J, and Chitemi C, (2009). Collective action initiatives to improve marketing performance: Lessons from farmer groups in Tanzania. Food Policy, 34: 53-59

Baloyi J.K, (2010). An analysis of constraints facing smallholder farmers in the Agribusiness value chain: A case study of farmers in the Limpopo Province. Unpublished dissertation retrieved on 25th March 2013 from: http://upetd.up.ac.za/thesis/available/etd10252010-195609/unrestricted/dissertation.pdf

Materechera S.A, (2011). Soil salinity in irrigated fields used for urban agriculture under a semi-arid environment of South Africa. African Journal of Agricultural Research, 6(16): 3747-3754

Moobi M.N, and Oladele O.I, (2012). Factors Influencing Small Scale Farmers' Attitude and Participation in Formal Financial Markets in Mahikeng Municipality, South Africa. Journal of Human Ecology, 39(1): 11-17

Newton J, (2013). The Importance of crop Insurance and how MIS will help to develop their future packages in particular to the small scale farmers of Uganda. Internet file retrieved on 15th July 2013 from: http://www.slideserve.com/pooky/the-importance-of-cropinsurance-and-how-mis-will-help-to-develop-their-future-packages-in-particular-to-the-small-scale.

Ozowa V.N, (1995). Information Needs of Small Scale Farmers in Africa: The Nigerian Example. Internet file retrieved on $26^{\text {th }}$ August 2013 from: http://www.worldbank.org/html/cgiar/newsletter/june97/9nigeria.html.

Matungul P.M, Ortmann G.F, and Paper M.C.L, (2002). Marketing Methods and Income Generation amongst Small-Scale Farmers in Two Communal Areas of Kwazulu-Natal, South Africa. Paper prepared for presentation at the 13th International Farm Management Congress, Wageningen, The Netherlands, July 7-12, 2002

Samantaray S K, Prusty S and Raj R K, (2009). Constraints in Vegetable Production-Experiences of Tribal Vegetable Growers. Indian Research Journal of Extension Education, 9(3): 32-34.

Senyolo G.M, Chaminuka P, Makhura M.N and Belete A, (2009). Patterns of access and utilization of output markets by emerging farmers in South Africa: Factor analysis approach. African Journal of Agricultural Research, 4(3): 208-214.

Saxena S, (2008). Increasing Income by Improving Marketing Strategies for Small Scale Organic Vegetable Farmers in Tanzania. University of Hohenheim, October 7 - 9, 2008 Conference on International Research on Food Security, National Resource Management and Rural Development. Internet file retrieved on $6^{\text {th }}$ June 2013 from: http://www.tropentag.de/2008 labstracts/full/113.pdf.

Cong T.N and Baldeo S, (2006). Constraints Faced by the Farmers in Rice Production and Export. ${ }^{1}$ Cuu Long Delta Rice Research Institute ${ }^{2} \mathrm{Head}$ of the Division of Agricultural Extension, IARI, New Delhi, India. Omonrice 14pp. 97 - 110. Internet file retrieved on 09th September 2013 from: http://www.clrri.org/ver2/uploads/noidung/14-12.pdf.

Uchezuba I.D, Moshabele E, and Digopo D, (2009). Logistical estimation of the probability of mainstream market participation among small-scale livestock farmers: a case study of the Northern Cape Province. Agrekon, 48(2): 171 - 183

World Development Report (2008): Agriculture for development, The World Bank Washington, DC. Internet file retrieved on 31st March 2013 from: http://siteresources.worldbank.org/INTWDR2008/Resources/WDR_00_book.pdf.

Xaba B.G, and Masuku M.B, (2012). Factors Affecting the Choice of Marketing Channel by Vegetable Farmers in Swaziland. Internet file retrieved on $5^{\text {th }}$ May 2013 from: http://dx.doi.org/10.5539/sar.v2nlp112. 